University of Louisville

ThinkIR: The University of Louisville's Institutional Repository

Electronic Theses and Dissertations

8-1947

\title{
Present day elementary school practices in reporting pupil progress to parents.
}

Dorothy Sternberg

University of Louisville

Follow this and additional works at: https://ir.library.louisville.edu/etd

Part of the Education Commons

\section{Recommended Citation}

Sternberg, Dorothy, "Present day elementary school practices in reporting pupil progress to parents." (1947). Electronic Theses and Dissertations. Paper 2175.

https://doi.org/10.18297/etd/2175

This Master's Thesis is brought to you for free and open access by ThinkIR: The University of Louisville's Institutional Repository. It has been accepted for inclusion in Electronic Theses and Dissertations by an authorized administrator of ThinkIR: The University of Louisville's Institutional Repository. This title appears here courtesy of the author, who has retained all other copyrights. For more information, please contact thinkir@louisville.edu. 
PRESENT DAY ELEMENTARY SCHOOL

PRACTICES IN REPORTING PUPIL

PROGRESS TO PARENTS

A profossional paper

aubmitted in partial fulfillmont

of the requirements for the Degroe

Master of Education

by

Dor othy Sternberg

August 15, 1947 
This PDF document is a scanned copy of a paper manuscript housed in the University of Louisville (UofL) Libraries. The quality of this reproduction is greatly dependent upon the condition of the original paper copy. Indistinct print and poor quality illustrations are a direct reflection of the quality of materials that are available for scanning. The UofL Libraries greatly appreciates any better copies that can be made available for replacement scans. 
NADE SF SIUDENT:_ Dorothy Sternberg

TITLE OF PROFESSIONAL PAPER: PRESENT DAY

ELENENTARY SCIOOL PRACIICSS IN REPORTING PUPIL

PROGRESS TO PARENTS

APPROVED BY READING COMIITEE COIPOSED OF TAE FULOUTIG MEMBERS:
C. W. Swink

J. J. Oppenheimer

NAIT OF DIRECIOR: J. J. Oppenheimer

DAIE: Ging, 27,1947. 
I. Introduction

II. Critoria for Roport Cards

III. Current Report Card Practices

IV. An Elementary Report Card Suggested for Discussion and Trial in a Socond Grado of a Louisville Public School

V. Conclusion

VI. Bibliography 
PRESENT DAY ELEMENTARY SCHOOL PRACTICES IN REPORTING

PUPIL PROGRESS TO PARENTS

\section{Introduction}

Sighs and groans abound when the elementary school teacher sits down at her desk to hor umwelcome task of marking hom report cards. For the teacher knows just how difficult her task is. Shall she give the intellectually superior child another perfect $r$ ow of " 1.8 " or " $A \cdot 8$ " or "Superiaris" to adorn his report card, so that he may march triumphantly home to claim his due rewards and praises? Must she do this though she knows the child is capable of much better work than ho has produced, moroly becruse he surpassed his classmates on a few written tests, or because he solved more arithmetic examples in a given timo than his classmates?

Must she mark the plodding, painstaking, sincerelytrying but intelloctually-handicapped ohild with another heartbroaking $r$ ow of " 3 's" or "U's" or "F's", merely because he cannot keop up with the standards set by his more gifted classmates, even though the child has improred upon his own past record in skills and knowledges? Shall she renture to stretch a few points and give this child better marks, to make him foel happier? But thon, suppose this child transfers to a now school or class? Will not the teacher como in for criticism for being suoh an "easy marker"? 
Unfortunately, in many elementary school systems, the answer is, "Yes." The form of the report card, the philosophy underlying the educational system, the parents' expectations, make "yes" imperative.

The parents of the "superior" child would certainly wail at and berate the teacher who dared to give "low marks" to their gifted progeny.

Yet, teachors and principals, using the traditional competitive marking systom, have always come in for criticism. The evidence clearly seoms to show that many report cards have failed to achieve their purposes. They have ongendered mistrust between parents and teachers, they have fostered foars and dislikes betwoen teachers and pupils, they have oven started noighborhood quarrels. So numerous were parental complaints about teachers and marks that H.V. Baker says:

There was a time when many elementary prinoipals made it a point on cortain days to be in parts of the building other than the office to avoid possible personel visits or telephone oalls which might be made. That cortain day was the day after roport cards were issued. 1

Neither parents nor teachers have over been complotely satisfied with the types of roport cards that were in common use fifteen af twenty years ago and are yet too often to be found. The unfortunate side of the situation is that parents, on the whole, do not realize just how dissatisfied the teaching profession has been with the traditional types of home report cards. For the

1. Bakor, H.V., "Roporting Pupil Progress to Paronts", National Elomontary Principa 1, 23:32, June, 1944. 
parent, the roport card is the real ovidence of his child's school progress. Often, the parent, who grow up in schools using the traditional report card, knows of no alternativo to it. Perhaps he belleves wholeheartedly in the "three $P^{\prime}{ }^{\prime \prime}$, because that is the way ho was taught, and no ono has made any roal offort to rovise his opinions. Ho may oren be suspicious of any rariation in it. Sohools have failed to keop parents fully informed of changing educational ideals.

However, mong the teaching profession, there here boen many survoys of report card practices, and my statements of the functions of home report oards. New forms $f \alpha$ hom roporting have been devised and used. There have been reports of the successful introduotion to parents of the nower conoepts of education. Thero are report, cards which consist only of informal lotters to the parents. Other roport cards contain sevoral pages of itoms to be marked.

There have beon attempts to heve the parent roport about the child to the sohools- in contrast to the traditional practice whereby the teacher reports to the home. There are home report cards in which the pupil himself propares his roport, or assists in its proparation.

Noill, in the Problem Teaoher, assorts that roport cards are undesirable, but that if they are to be rotained, he proposes that thoy should be written by the children themselves about themselves, with an appendix about each teacher.1

1. Noill, A.S., The Eroblem Teacher, Internstional University Press. 1944, 16I pages. 
Reports to parents are statements that the public schools sond periodically to parents showing how their childron are progressing in their school work. They are a means of bringIng the hom and the school into closer relations. The traditional roport card containod marks, usually in the form of perconts, in various subjeots. These marks had two main purposes, first, to protect the teacher from undue oritioism for failing pupias without previously informing the parent of the child's deficiency, and, sec ond, the pupil was to be stimulated to do better work by knowing his "grades", and by knowing that his parents also know them.l Emphasis was upon the subject, not the learner. There was no question in the mind of the parent concerning the philospphy of -ducation behind this sort of roport card. It met with little criticism from them. It was on the surface spocific and clear cut. The parent did not roalize how ridiculous it was to assume that toachers were so infallible and such good judgos of achievement that thoy were able to say that Sam Jonos' work was worth $92 \%$ and Bill Smith's work 92.6\%. Bill Smith's work may not have heon as good as Sam Jones'. Perhaps Bill Smith had a nicer smile, or didn't talk back in class. At any rate, the parents wore satisfied with percents. Educatbrs wero not. They thomselves began to realize the futility of such a grading systom.

With gradual changes in philosophy of education bocoming

1. Heck, Arch 0., Encyc lopedia of Modern Education, Rivlin, H.N.) Ed., Schueler, Herbert, $\Lambda_{B}$ so. Ed., Philosophical Library of Now York City, 1943, pp. 667-668. 
apparent, a survey mas made in 1925 by Chapman and Ashboughl in order to determine just how far report cards were lagging bohind oducational practices. The result of this survoy was that oducators began to quastion the validity of the traditional report card. If the traditional type of report card has boen judged to be inadequate for the elementary school, just what criteria are to bo sot up for the now report card? What are valid items for it to contain?

Modern philosophy of oducation considers that education is a process of growth of the whole child, not morely of that part of the child from the neok up. Therefore the report to the parent must. be concernod with the whole child, with his social and physical growth, as well as with his intolloctual growth. Hanson states:

The maker of this report card must realize that education is not only a matter of accumulated knowledges and skills in using the tools of subjeot matter, but it is a question of making social adjustments, thinking cloarly, facing facts fearlessly, and making judgmonts based on woighed evidence. The roport card, then, should offor a practical method (1) of offering constructive and ouggestive holp to the paront, the child, and the teacher; (2) of rating all phases of growth a and developmont, 18 . social, physical, emotional, intellectual; (3) of administration so that too much time in marking is not expected of a teacher.2

Hansen indicates that the following objectives might be shown on report cards:

1. Correlation of subject matter

2. Rocognition of indiriduel differences

1. Chapman, H.B. \& Ashbaugh, E.J., "Roport Cards in Amorican Cities", Educational Research Bulletin (Ohio State University) IV (Oot. 1925) pp. 289-298.

2. Hansen, Rowna, Report Cards for Kindergarten and Elomentary Grades, U.S. Dept. of Education, Washington, D.C., Ieaflet \#41, p. 20. 
3. A statement on the roport card of the conter of interest around which class work has beon organized

4. Beharior development

5. Use of standardized achievement tests

6. Rocognition of extracurricular activities

7. Encouragement of appreciative and croative expression

8. Cooperation of school and home.1

Mettoor statos the following criteria for reporting

pupbl progress to parents:

1. The mothod of roporting should represent the philosophy and purposes of the school where used.

2. The mothod of reporting should be clearly understood by children and paronts.

3. It should include no itoms for ratings which cannot be reported with considerable couraoy.

4. It should be noat and attractiro.

5. It should be retained by the parent after its last use.

6. Any notice of unsatisfactory work should be accompanied by an explanation of the causes of the difficulty and by suggestions for romedial mossures.

7. It should not maks undue demand upon the timo of teachers.

8. It should contain no comparis ons with other children.

9. The child should hare an opportunity to assist in eraluating his own growth for the report to parents.

10. The tone of the report should be rarm and personal.

11. The report should include an estimate of the growth of tho child in all its aspects, intellactual, physical, social, and omotional.

12. The reporting systom should be flexible.

13. The report should be a confidential matter.

14. The report oard should be supplemented by at least one conference with parent or parents, at the school.

15. The reporting systom should be a tro-way communioation botween the hom and the school.2

1. Ibid.

2. Wottoer, W.M., "How California Elomentary Schools Report to Parents", California Journal of Elomentary Education, $10: 135-151$, Fob., 1942 . 
Lindel and Nohr add the following to the list of oriteria montioned above:

1. It should pormit as complote a pioture as possible of the child.

2. It should roquire as much thought as possiblo on the part of the teacher, and at the same timo as littlo effort as possiblo in maing it out.

3. It should perdit tho teacher as much latitude as possiblo so as to peovide for any eventuality.

4. It should be uniform throughout the sohool.

5. It should not be impersonal and narrowly exolusive such as ohecks in littlo squares.

6. It must not deal in gonoralitios but must bo spooific, directing attention to the mountains and valloys in the porsonality of each individual child.

7. It must corer the fiold.

8. It must be honest and constructive.

9. It must be kindly in tone and profossional in spirit.

10. It must not be confused with attempts to tell overything about the child, but must limit its 1 scope to one or two points under each hoading.

They recomend the followins type of repart card:

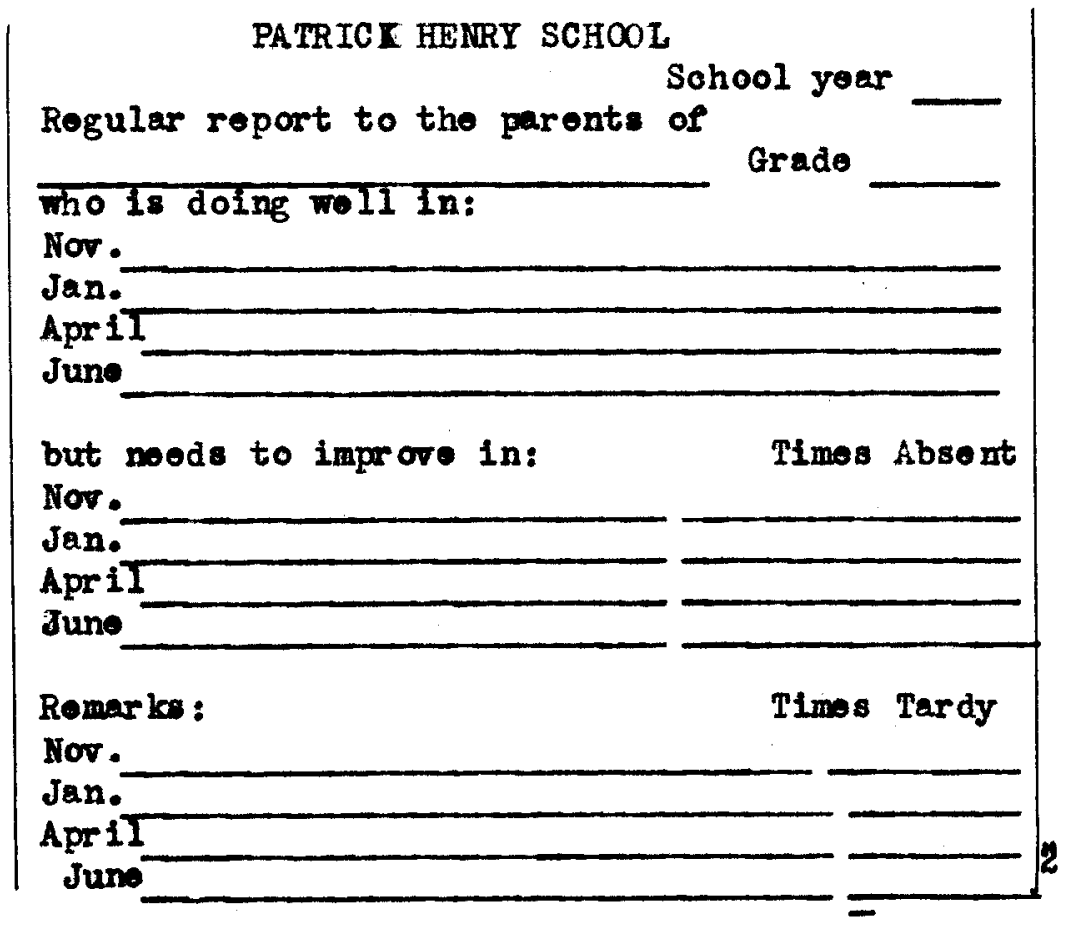

1. Lindell, Albort L. and Mohr, Allene, "The New Report Card," National Elomentary Principal, 25: 39-41, Oct., 1945.

2. Ibid. 
For oduoation in a demooracy, there cannot be any ono philosophy of oducation. It is the right of each community to possess its own philosophy of duoation which is adapted to its own needs. Therefore, no one person or group should set up any hard and fast rulos about the kind of roport card to bo used. Howover, it is essential that every school system formulate a statement of its philosophy of education, expressed in clour and understandablo terms, and then plan a report card which will portray its program. The objectires of the school should be stated clearly, and the report card should be designod to report in accordance with them. An N.E.A. bulletin expresses the following as an underlying philosophy of Amorican education:

1. The school must become a thoroughly damow cratic institution in which the ways of democracy are learned and practioed.

2. The continuous growth of the whole child to the fullest extent of his or hor ability is fundamental to the child's own good and that of society.

3 . Instruction hould be adapted to the rarying neods and difforenoes among individuals.

4. Learning is best achiered through worthwhilo experiences, individualized and socialized. .

5. The enlightened citisen of tomorrow is the onlightened junior citizen of today.l

Trans lated into implications for a reporting systom, it follows that:

1. Rating hould take into account the growth of the whole ohild - not morely in relation to subject matter alono - but in rolation to his or hor total bohavior as an individual and $a s$ a momber of a democratic society.

2. Ratings sould tako into account the pupil's ability to achieve.

3. Rating sould aroid a competitire basis. The most desirable competition is competition against one's self, for no one can grow for another. Progress therefore troceods step by stop for esch pupil in excolling his or hor own provious record.1

1. Berman, Sanuel, "Revising the Junior High School Report Card," The Bullotin, National Association of Socondary School Principals, $\overline{\mathrm{N} . \mathrm{E}} . \overline{\mathrm{A} ., \mathrm{XXVII}}$, No. 115, May, 1943. 
To sumarize the in points:

1. Report cards should take into consideration more than more subject atter, including other phases of child growth such as physical, omotional, othioal, wosthotic, and $801 a l$ growth.

2. Report cards should state the oducational objectives of the school.

3. The report card should aroid all competitive elements except competition against one's own record.

4. Report cards should be speoifio rather than general.

5. Report cards should make constructive sutgestions where improvement is desired.

6. Report cards should express cooperation between the home and the chool, and contain an invitation for the parent to visit the sohool and confer with the teacher.

7. Report cards should not be complicatod for the teacher to make out or for the parent to understand. 


\section{Current Repart Card Practicos}

Present report cards in use throughout the United States vary pridely with respoct to their form and typo. Some of the general types may be classified as follows:

1. Traditional types of report card

These report on subject mattor only, with one or two other itoms listed under the comprohensive torms of "conduct" and "offort". These roport cards are marked with percentages, or with lettors such as E (Excellont), VG (Vory Good), G (Good), F (Fair), $P$ (Poor). The lettors havo poroentago equivqlents as follows:

$$
\begin{aligned}
& E-95 \%-100 \% \\
& V G-88 \%-94 \% \\
& G-80 \%-87 \% \\
& F-70 \%-79 \% \\
& P-0 \%-69 \%
\end{aligned}
$$

In other words, oven though the letters are used, the ropat card is actually a porcentago ropart card. It is built to promoto compotition.

2. Formal Roport Cards (A revision of the Traditional typo card) Those report on subject metter, and most often contain also a roport on character, citizenship, personal and social habits, and sometimes contain a report on the health of the child. In form, they aro somewhat like tho traditional report card, with littlo squares for checking or marking. Quite often, this type of roport card contains a space for a teacher's comment or messago. Sometimes, there is also a space for a parent's roply. A majority of schools at the present time use some variation of this typo of roport card.

3. Informal Report Cards

These aro individually propared letters written by the 
teacher to the parents, reporting on the progress of the child. Som inform l reports consiat moroly of letter heada containing the name of the school or city. Some have indioations of phasea to be disoussed, with spaces for the teacher to writo hor commonts. Some have speces for the parents to write their responses. More and more school systems soom to bo undertaking at present the experiment of trying out this report card. There are a great many advantages, but also many disadvantages to its adoption.

In the first place, it does away with the nocessity for marks alt ogether. Educators are coming to fool mare and more that the use of marke is not commendable. Dr. Laura Zirbes says:

There can be no doubt of the need for oubstitute procodures in the case of such probboms concerning marks, grados, and promotion. Wo have sot up these medes of report. They are undor criticism because they have diverted offort and attention from worthwile ends. They are at the bottom of diahonesty to secure marks and to pass oxaminations, of subterfuges used to get by. The demoralizing offects of compotition on children who are most in need of encouragement and least able to compete fairly for marks and promotion are only part of thia story. They have another bearing. During the very years in which childron shotid be exposed to the congenial climate of 800 ial interaction and cooperative ondeavor for the cormon good, they are systematically exposed to the rigors of competition, sorted into rankings and groupings, and rogimented into mass action.1

The personal letter report has the advantages of informality, of giving more ocaplete infarmation concerning the child's strongths and weaknesses, and of doscribing ways in which the child may be helped to improve.

1. Zirbes, Laura, "The Emotional Climate a Schools." Educational Mothod, XIV: 171-173. Jan. 1, 1935. 
Schools who are trying out this mothod of reparting to the home seem to have attained good results through its use. Howerer, this type of roport card involves many problems. The first is the reluctance of teachers, with large classes, to give of their time to write the lotters. There is also the diffloulty of finding time to become well enough acquainted with thirty or forty pupils in order to be able to writ an Informativo letter about each. A third problem is the avoidance of stereotyped phrases and letters. There is the fauth problem of satisfying parents who are accustomed to marks and who want to know how their children compare with others of their age and grade. Thero is also great liklihood of paronts misuhderstanding teacher's romarks. Another phase of the problem is that Junior High Schools want marks when pupils are transferred; a lso marks are desired by a new school whenever a child transfers. For all these reasons, marks must be kept for office records, so the teacher in such a sohool system really gots a double dose of reporting.

It may bo of interost at this point to examino samples of the three types of report cards mentioned. 


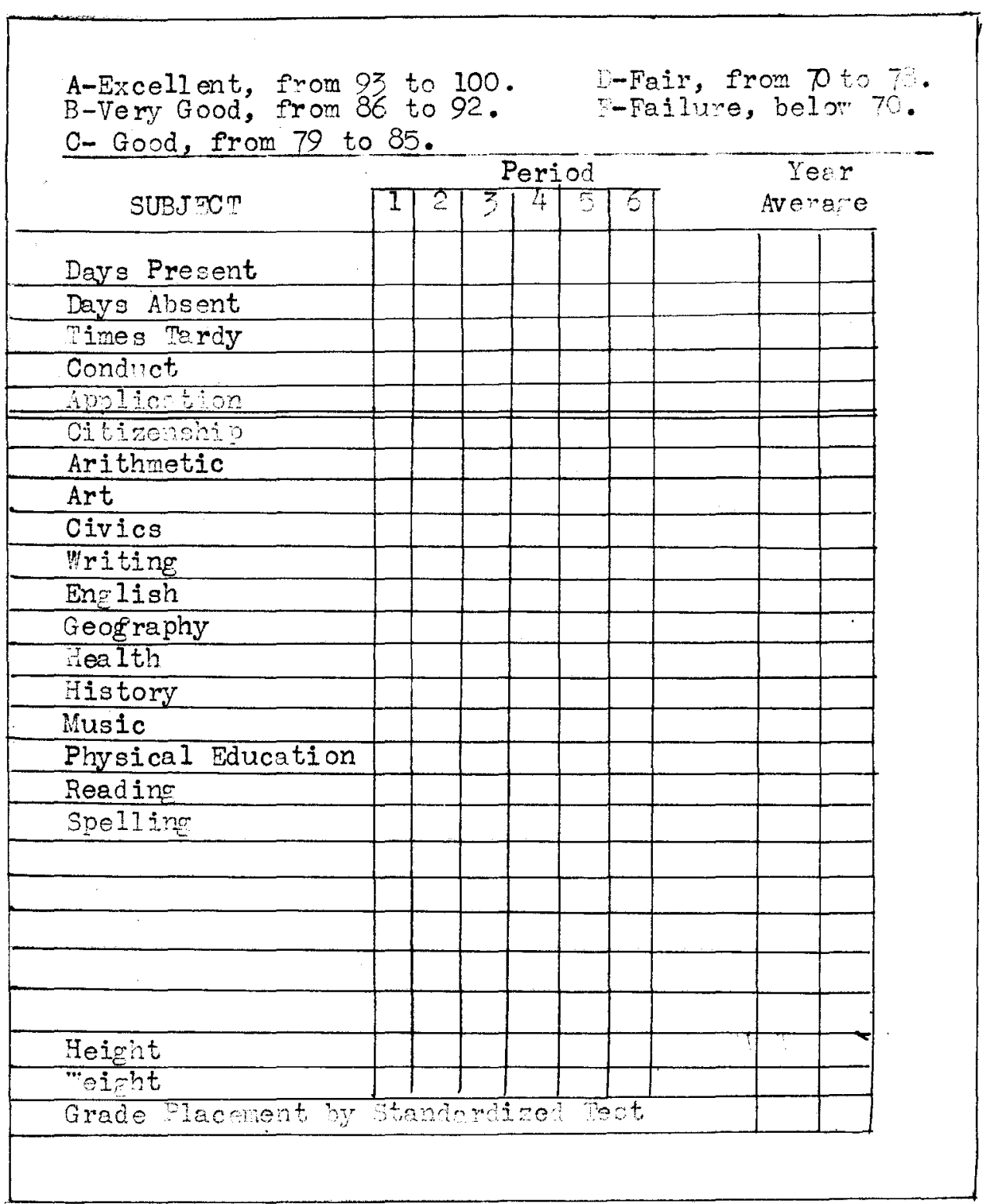

SATPLE I. A TRADITI NTAL - TYPE REPORT CARD ${ }^{I}$

Elementam Report Card, Jefferson County Public Schools, Jefferson County, Kentucky. 


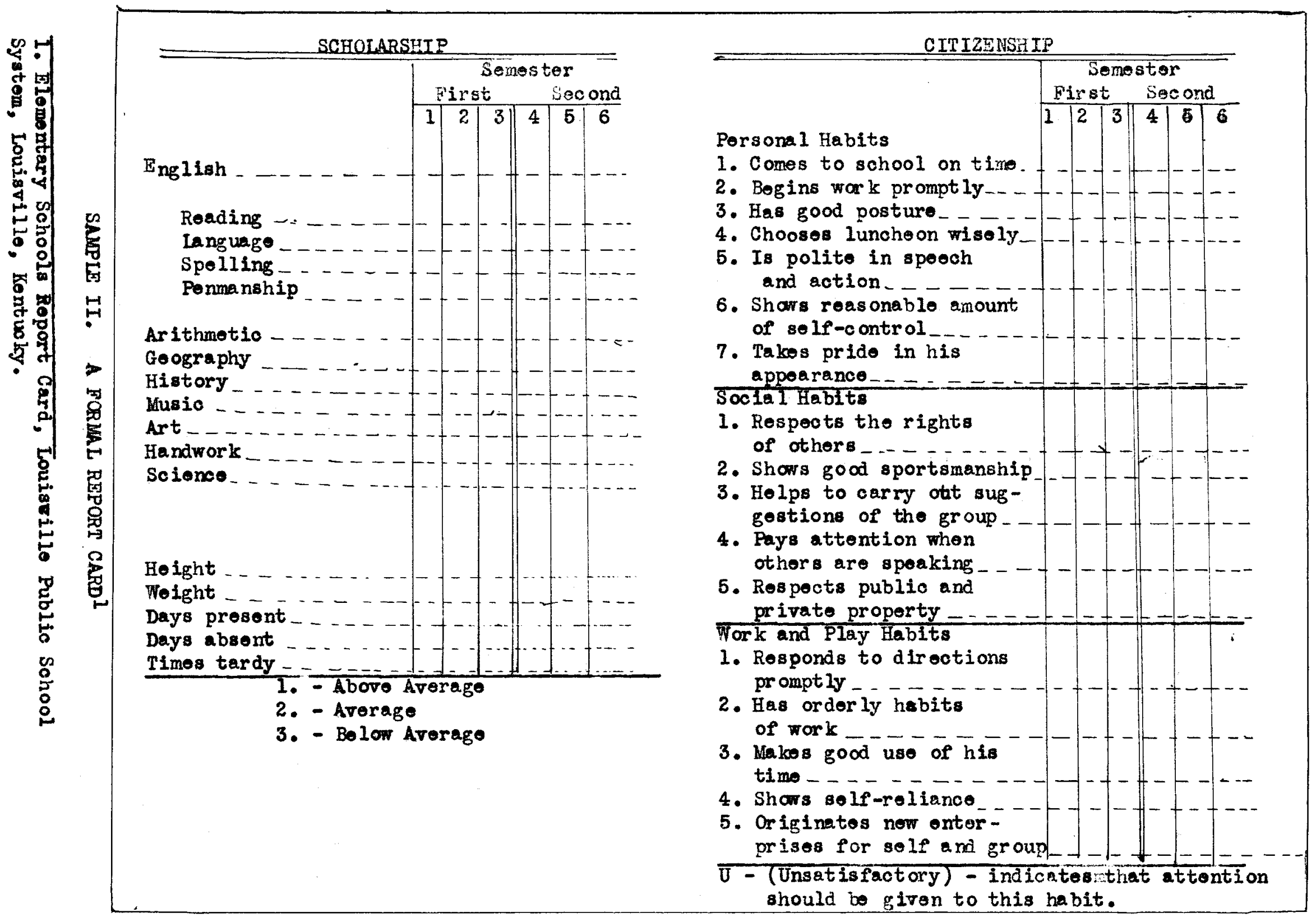




\begin{tabular}{|l|l|l|l|l|}
\hline & First Period & Second Period & Third Period & Fourth Period \\
\hline & Growth in & & & \\
\hline \\
\hline
\end{tabular}


The three sample report cards shown above merely indicate types on which there are innumerable variations. There are, for example, many different and confusing mothods of reporting school marks. The percentege mothod is one of the oldest. It is still quite provalent in use throughout high schools, but has como into disuse almost ontirely in olementery schools at present. The letter mothod, A, B, C, D, F, is often used. As the letters are usually interpreted in the form of percontages, there is very little difference in this mothod fran the percontage mothod. other cities use numbers, such as $1,2,3,4,5$. This is another variation of the percentage method. The current trend, where numbers aro used, seems to be toward using less then five, porhaps two or three numbers, auch ase used on the Louisville Public School Elementary Report Card at the present time. This might be called the throe graup mothod, based on below average, average, and above average porformance. The "descriptive" mothod is sometimes used. It omploys such terms as "excellent," "hoeds to improve," and "poor rork." The rank mothod, which has nover been widely used, indicates by a numorical ranking, where a child stands in his group.

In 1925, Chapman and Ashbaugh examined 452 elementary roport card forms, and showrod mothods of roporting school marks to parents as follows: 


\section{TABLE I}

\section{METHODS OF REPCRTING ELEMENTARY SCHOOL MARKS TO PARENTS AS FOUND IN 1925 BY CHAPMAN AND ASHBAUGH}

Rating Wothod

Porcentage
Lotters tran lated
Lotters
Group
Sympol
Graph
No rating

\author{
Percentage employing \\ each method \\ Elementery School
}

$$
\begin{gathered}
29 \% \\
35 \% \\
17 \% \\
7 \% \\
8 \% \\
0.5 \% \\
3.5 \% 1
\end{gathered}
$$

A.0. Heok, in a book publishod in 1929, reports that, "In aotual practice mothods of reporting marke heve gone but littlo beyond the older porcentage mothod."2

One of the major objections of educators to the traditional type of report card as well as to those revised types of roport cards which yot are based on competitive grading systems, or even to the informal letter type of report card in some instances, is the offect that a compotitivo marking may have upon the montal hoalth of the child. To a child of low ability, it is not only discouraging, but oven harmful, to bring home an unfavorable report card timo after time. A child who has conscientiously dono his best to comply with the requiremonts of grade, and who has shown incroased shills and knowlodges, to the bost of his ability, even though his achierement is less than that of his classmates, is entitlod to rocognition for that success he hes achiered.

1. Chapman, H.B. and Ashbaugh, E.J., "Report Cards in American Cities", Educational Research Bulletin (Oct. 7, 1925), Vol. IV, p. 290.

2. Heck, Arch 0., Administration of Pupil Personnel, Ginn and Co., Boston, 1929, p. 291. 
Undue stress upon attaining high marks may give a child an inforiority complox which will affect his ontire life, may cause him to cheat, lie, and copy, or may set up the stage for other defonse mechanisms, such es "nervousness". Every child noeds some experienoes in which he enjoys success and praise. Preston says that, unless there is some amount of praise, "the child's self-confidence and self respect are eventually damaged. Serious damage to the self-rospect can bo the basis for mental 11 Iness..."1

He continues :

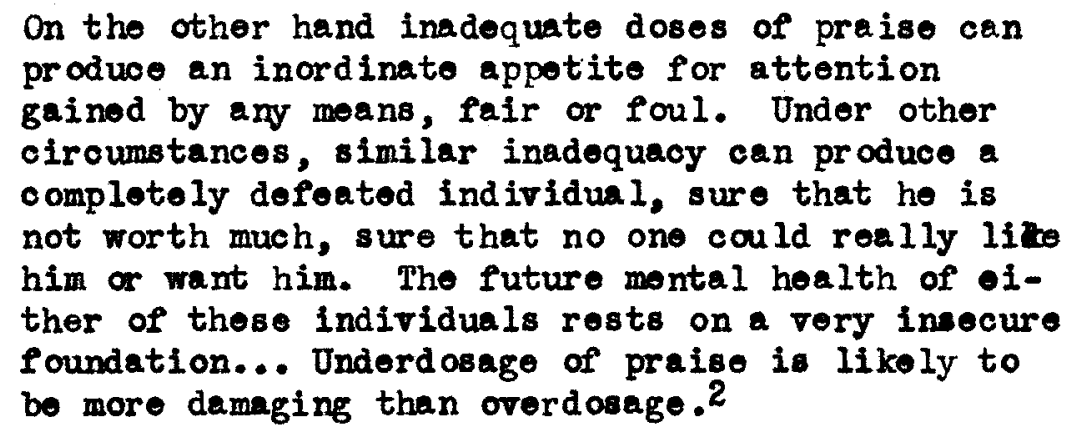

Competitive marking systems contradict known facts about

indiridual differences in ability, in rates of loarning, and in interests. The accomplishmont of other pupils shoud have no bearing upon what ono pupil has done. Grading should not be based upon whether one pupil is better than another, but upon whether the pupil has learned or not. Compotitive marking distracts the attention of the pupil from desirable learning outcomes to numbers of problems solved, numbers of facts memorized, number of drill oxorcises completed.

On the other hand, from all points of view, it would bo

1. Preston, Goorge H., The Substance of Mental Health, Rinohert \& Co., Inc. N.Y. 1933, Pp. 138-139.

2. Ibid. $v$ 
vory poor policy to deceive the parent consistently concerning the kills and aptitudes of his child by sending home glowing reports, when they would give the parent a falso picture of his ohild. The parent has a right to know the truth. Roos reports an interosting and uncomplicated method for roporting on the child with low ability, in a system which uses a compotitivo marking systom, so that tho child may rotain his solf-rospoct.

These cases are sonsibly and humanoly cared for in the nw roport card by a noto under The Teacher's Remarks that, "This pupil is marks according to his ability and not according to oustomary grado ratings." His card is a good card. Ho knows that he cannot road and clpher, but he knows also that he can bo a worthwhile and approciated momber of his class, and his report card helps him by giving him the writton ovidenoe. On the othor band, no one is decoirsd whose businoss it is to know and understand. The roport card may bo prosentod with his transoript anywhere and the rocoiving school has all tho necessary information to procood with his placemont with no ombarassmont to pupil or parent.l

The effoct of competitive marking upon the superior child has often been orerlooked. He finds that he can do better work than the child of lower ability, without oven half trying. There is no incentive for him to try to do more or botter work. Ho is already at the top of the class! In fact, by working at perhaps only half of his capacity, ho is doing moro than just gotting by. Is ho ontitled to better marks than the child who is working at the top of his capacity? Surely it is better that the superior child work to surpess his own previous record. Then ho has some incentive to koop on at his highest capacity.

1. Roos, C.A., "Report Card Designed to Enlist the Parent's Cooperation in Rating and Guiding the Child". American School Board Journa 1, 107: 28, Aug. 1943. 
Nany poople, toachers as well as parents, believe that compotitive marking is all right. They say that sinoo compotition is the rule of life, therefore pupils had botter loarn to oompote. Some contend that competition is right and proper, and that cooporation grows from compotition. For cxample, on the football fiold, cooperation among toamates is rery high bocause of tho fact that a compotition is going on.

It is trus that competition is the rule of life, but it is also the cause of many ovils, ospocially in the fiold of montal hygiene. Competition among adults, in specialized courses, in technical training and the 12ke, may bo justified. Who is to say how much of the competition we seo around us is the product of the competitive marking systems of the schools from which the adults of today have come. Education in a democracy implies cooperation rather than compotition.

That there are orils in the systom of competition is oridonced by recent limitations our government has placed upon it. Prico ceilings, ront coilings, wago and hour laws are all instances showing how competition is being curbed at the prosent time.

The personality defocts result ing from compotitive marking systoms soom to outwoigh the oridence supporting competitive marking.

In the present yoar, 1947, there is evidently very groat offort to get away from the competitive and porcentage mothod of marking. The change has boen a gradual one, since it sooms difficult for parents and teachors to give up the traditional concept of marks. As will be shown on the chart presented on page $24,8 c h o 0 l$ 
systoms, especially olementary school systems, and still moro espocinlly the primary grades of the olomentary sohool systems, are exporimonting with many other ways of marking reports. There is a trond toward using "S" and " $U$ " (Satisfactory and Unsatisfactory). This doos aray with ny of the psychologically harmful foatures of marks.

The multiplicity of marking systoms in use at prosent adds further to the confusion apparent in the struggle to improve home roport cards in the elemontary school. On some cards, an " $X "$ is the symbol for outstandingly supericr progress; on other cards, an " $\mathrm{X}$ " symbolizes unsatisfactory work. On some oards, "I" means "Improving". On other cards, "I" means "Is able to do bettor". There seems to be a need hore for more uniformity and agreomont upon the meaning of symbols, since wany children in the United States transfor from city to city sovoral times during thoir elomentary school life, and must prosent their roport cards fran provious sohools when thoy onter a now school. Motteer suggests the elinination of symbols, and the use of columns with descriptive hoadings. 1

There are other probloms concorning olementary school report card practices which are of concern at the prosent time, whon many now report oards aro boing devised and triod out. Somo of those probloms aro:

1. How many levels should there be on a grading soale, and what sort of grading scalo is advisablo.

1. Motteor, W.M., "How california Elementary Schools Repart to Paronts", California Journal of Elomontary Education,

10: $135-151$, Fob. 1942. 
2. Hor many form of roport oard should bo used in the elementary school? Should the same form be used from Findergarton through Grade VI? If not, how my different forms seom best?

3. How shall subjects bo listed? As soparato subjects, or grouped into a fow wide areas of interest?

4. Should subjects bo listed by name only, or should thoy further be subdivided into their component parts, as, for oxample, the Elewontary Report Card used in Saginaw, Michigan, doos. Under the in subjoct hoading, Arithmotic, this report card contains the following items to be checkod:

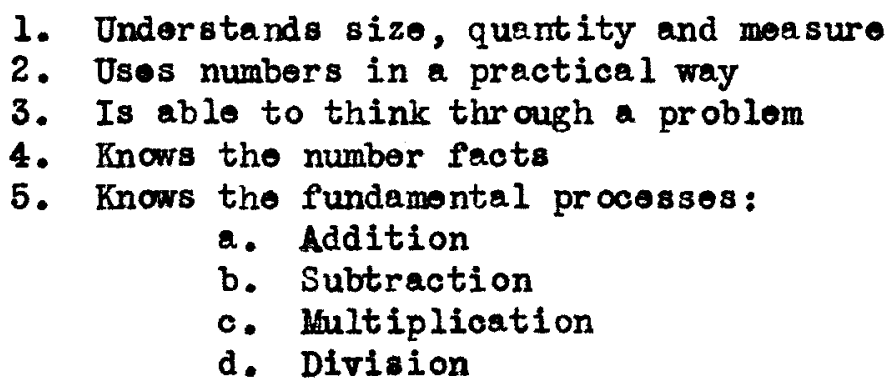

5. How shall oitizenship, character, sooial growth, and health be expressed on the report card? Should they be expressed by one word generalizations, such as Courtesy, Obedience, and Promptness, or shauld descriptive phrases of spocific acts be used, 0.g. "Follows directions promply", "Waits until others are finishod before talking", and "Doos his work quietly". Furthormore, should they be expressed in a positive or a negative way?

6. Should there be a space provided on the report card for a written comment or suggestion from the teachor?

7. Should there be a space provided on the report card for a written coment or a suggostion from the parent?

8. Should the child have a part in the making out of his own report card to his parents?

9. How many times a yoar should the report card be issued?

10. Should and explanation of the moaning and purpose of the report card accompany it to the homo?

11. Should grading be based upon a competitive scale or upon the individual ability of oach child?

12. Should there be a space provided on the report card for montioning special talents, skills, interests, ar services to the group?

13. Should formal report cards be roplaced by the informal written lotter? 
14. Should conferences botween parents and teachers at regular intervals supploment the use of the report card?

Bridgewater Cownship Sohool uses the following plan

for parental conferonces:

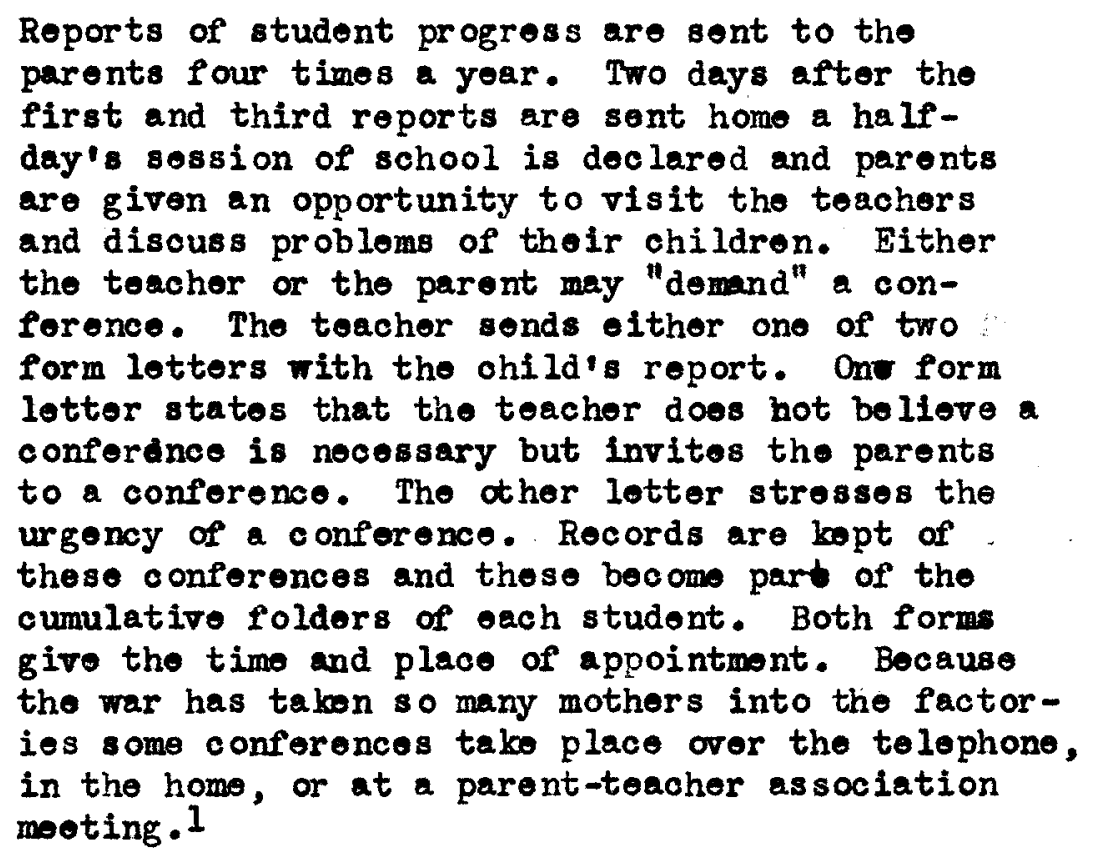

The following analysis has been made of group of representative roport cards used in elementary schools in various soctions of the United States at the prosent time, in order to gain some ineight into current tronds with rospect to these problems.

1. Saunders, Carlet on M., "The School and tho Community Work Together", How Jersey Elomentary Prinoipals, Vol. 17, No. 4, viay, 1944, pp. $\overline{5-6 .}$ 


\section{TABLE II}

AN ANALYSIS OF A GROUP OF ELEMENTARY GRADE REPORT CARDS IN CURRENT USE IN SOM

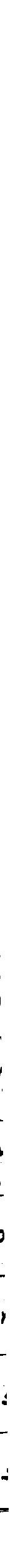


IE IN SOME PUBLIC

\begin{tabular}{|c|c|c|c|c|c|c|c|}
\hline 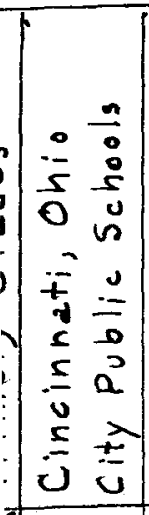 & 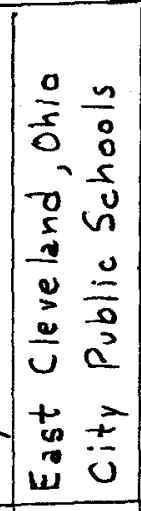 & 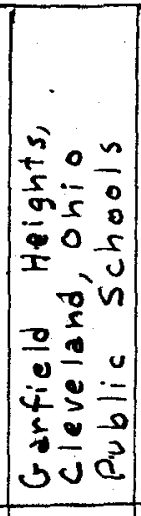 & 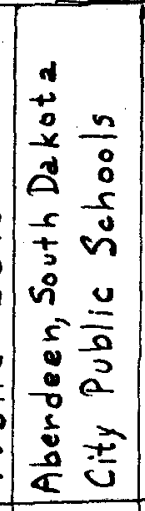 & 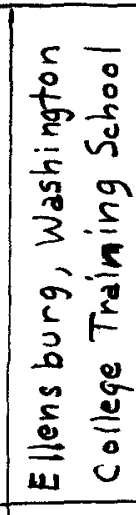 & 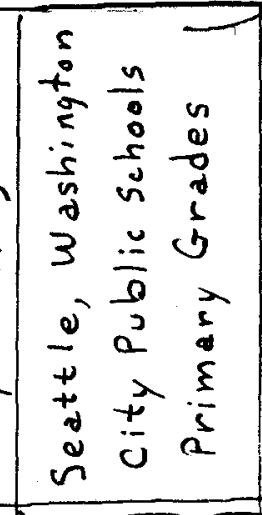 & 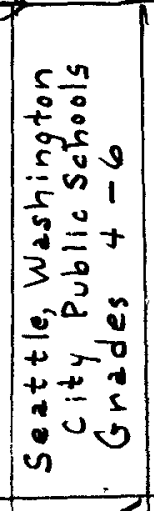 & I \\
\hline 3 & 1 & 2 & 1 & 2 & 4 & & \\
\hline$F$ & $F$ & $I$ & $I$ & $I$ & $F$ & $F$ & \\
\hline $\begin{array}{l}A, B, \\
C, O, E\end{array}$ & $\begin{array}{l}S, N \\
I, U\end{array}$ & none & none & none & 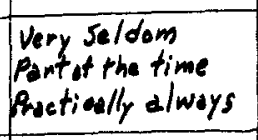 & $\begin{array}{l}A, S, U \\
(+-)\end{array}$ & \\
\hline $\begin{array}{l}A, B \\
C, D, E\end{array}$ & $\begin{array}{l}S, N, \\
I, U\end{array}$ & none & 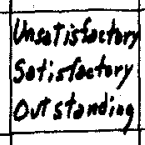 & none & 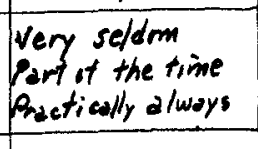 & $\begin{array}{l}A, S, 0 \\
(+-)\end{array}$ & \\
\hline 5 & 4 & none & nene & none & 3 & 3 & \\
\hline Yes & No & $\begin{array}{l}\text { Not } \\
\text { listed }\end{array}$ & $\begin{array}{l}\text { Not } \\
\text { listed }\end{array}$ & Yes & $N_{0}$ & No & \\
\hline yes & $\begin{array}{l}\text { Only } \\
\text { social } \\
\text { studies }\end{array}$ & Yes & $\begin{array}{c}\text { Not } \\
\text { listed }\end{array}$ & Yes & Yes & Yes & \\
\hline No & Yes & No & No & yes & Yes & yes & \\
\hline No & No & No & No & No & No & No & \\
\hline Yes & Yes & Yes & $\begin{array}{l}\text { On } \\
\text { citizen. } \\
\text { ship. } \\
\text { shiply }\end{array}$ & Yes & Yes & Yes & \\
\hline No & No & Yes & No & No & No & No & \\
\hline Few & Many & $\begin{array}{c}\text { Not } \\
\text { listed }\end{array}$ & Many & Many & Many & Many & \\
\hline Yes & Yes & Not & Yes & Yes & - yes & Yes & \\
\hline$y_{e s}$ & No & $\begin{array}{l}\text { Not } \\
\text { listed }\end{array}$ & Yes & No & No & No & \\
\hline
\end{tabular}


TABLE II, (Continued)

\begin{tabular}{|c|c|c|c|c|c|c|c|c|c|c|c|c|c|c|c|c|c|c|c|c|c|c|c|}
\hline $\begin{array}{l}\text { Is health described by a number of specific } \\
\text { phrases? }\end{array}$ & No & No & - & 2 & No & - & - & No & 6 & - & 2 & 3 & No & 3 & - & No & 5 & No & 4 & - & 4 & 3 & - \\
\hline $\begin{array}{l}\text { Is there a section in which the child eval- } \\
\text { untes himself? }\end{array}$ & No & No & No & No & No & No & No & No & No & No & No & No & No & No & No & No & No & No & No & No & $N_{0}$ & $N_{0}$ & No \\
\hline $\begin{array}{l}\text { Is there a statiment of the aims and purposes } \\
\text { of the school? }\end{array}$ & Yes & Yes & Yes & No & Yes & No & $N_{0}$ & Yes & Yes & No & No & Yes & Yes & No & No & No & No & Yes & Yes & No & No & No & Yes \\
\hline $\begin{array}{l}\text { Is there a request for cooperation between } \\
\text { the home and the school? }\end{array}$ & Yes & Yes & Yes & Yes & $Y_{e}$ & Yes & Yes & Yes & Yes & Yes & No & Yes & Yes & Yes & Yes & Yes & Yes & Yes & yes & Yes & Yes & Yes & Yes \\
\hline $\begin{array}{l}\text { Is there a suggestion for pa rents to make } \\
\text { visits to the school? }\end{array}$ & Yes & No & No & Yes & Yes. & $y_{e s}$ & No & Yes & Yes & No & Yes & Yes & No & Yes & Yes & No & Yes & Yes & Yes & $N_{0}$ & Yes & Yes & Yes \\
\hline $\begin{array}{l}\text { Is the report card explained to the parents } \\
\text { by a booklet, a letter, or other means? }\end{array}$ & No & No & No & No & $N_{0}$ & No & No & $N_{0}$ & No & $N_{0}$ & No & No & $N_{0}$ & No & No & Yes & Yes & No & No & Yes & No & No & No \\
\hline $\begin{array}{l}\text { Is there a space on the report card for } \\
\text { corments by the parent? }\end{array}$ & Yes & Yes & $y_{e s}$ & No & Yes & Yes & Yes & Yes & No & Yes & No & Yes & $y_{e s}$ & No & Yes & No & Yes & No & Yes & Yes & No & No & Yes \\
\hline $\begin{array}{l}\text { Is there a space on the report card for } \\
\text { comments by the teacher? }\end{array}$ & Yes & Yes & Yes & Yes & $y_{e}$ & Yes & Yes & Yes & Yes & Yes & Yes & No & Yes & Yes & Yes & $N_{0}$ & Yes & Yes & Yes & Yes & No & No & Yes \\
\hline $\begin{array}{l}\text { Is there an explanatory booklet or work- } \\
\text { sheet to help the teacher? }\end{array}$ & $N_{0}$ & No & No & No & No & No & $N_{0}$ & 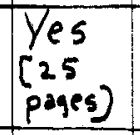 & No & $N_{0}$ & $N_{0}$ & No & $N_{0}$ & No & No & Yes & No & $N_{0}$ & $N_{0}$ & No & Yes & No & Yes \\
\hline $\begin{array}{l}\text { Is the report complicated for the teacher } \\
\text { to use? }\end{array}$ & No & Yes & Yes & No & $N_{0}$ & Yes & Yes & Yes & No & Yes & No & $N_{0}$ & Yes & Yes & No & No & Yes & No & Yes & Yes & $N_{0}$ & Yes & No \\
\hline Is the report easy for parents to understand? & No & No & Yes & Yes & No & No & Yes & Yes & Yes & Yes & No & No & Yes & No & Yes & No & No & Yes & Yes & Yes & Yes & Yes & Yes \\
\hline $\begin{array}{l}\text { Is any mention made of special talents, } \\
\text { skills, interests, or service to school group? }\end{array}$ & No & No & - & No & M & _ & - & - & No & - & No & No & No & No. & - & No & No & No & No & - & Yes & No & - \\
\hline $\begin{array}{l}\text { How many times a year is the report card } \\
\text { issued? }\end{array}$ & 4 & 4 & 4 & 4 & 4 & 2 & \begin{tabular}{|l|} 
not \\
stated
\end{tabular} & 4 & 4 & 4 & 6 & 6 & 2 & 6 & $\begin{array}{l}\text { not } \\
\text { stated }\end{array}$ & 4 & 6 & 5 & 4 & 4 & $k_{g}^{4}-2$ & 6 & 4 \\
\hline $\begin{array}{l}\text { Does the report card give a general impression } \\
\text { that marks are based upon ability or upon } \\
\text { competition? }\end{array}$ & Comp. & $A b_{i} \mid$. & Abil. & Abil. & Com & Abil. & Abil. & Abil. & Abil. & $\left|A b_{i}\right|$. & Comp. & Comp. & $A b_{i} l$. & Abil. & Abil. & Comp. & Comp. & Comp & Comp. & $\left|A_{b i}\right|$. & Comp. & Comp. & $A b ; l_{0}$ \\
\hline
\end{tabular}




\begin{tabular}{|c|c|c|c|c|c|c|}
\hline & 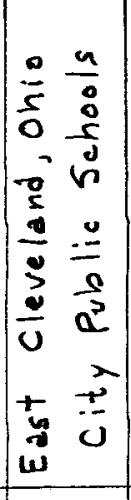 & 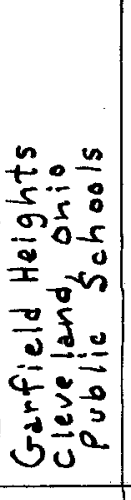 & 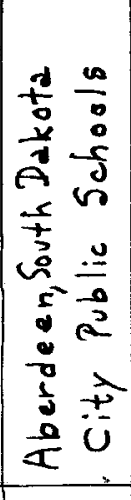 & 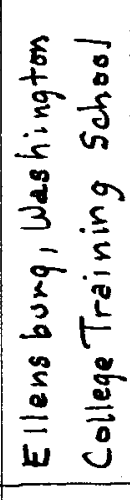 & 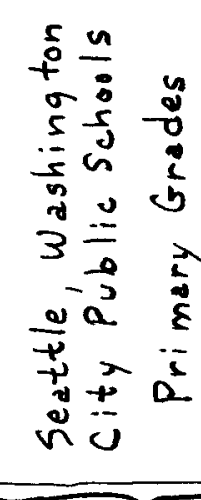 & 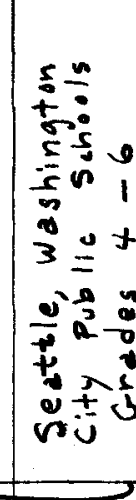 \\
\hline & 3 & - & No & 12 & 2 & 3 \\
\hline & No & No & No & Yes & No & No. \\
\hline & No & Yes & No & Yes & No & No \\
\hline & Yes & Yes & Yes & Yes & Yes & Yes \\
\hline & Yes & Yes & Yes & No & Yes & yes \\
\hline & No & No & Yes & Yes & No & No \\
\hline & No & Yes & No & Yes & No & No \\
\hline & No & Yes & Yes & Yes & No & Yes \\
\hline & No & Yes & Yes & No & No & No \\
\hline & Yes & No & No & Yes & Yes & Yes \\
\hline & Yes & Yes & Yes & Yes & Yes & Yes \\
\hline & No & - & - & - & No & Yes \\
\hline & 6 & 4 & $\begin{array}{l}\text { not } \\
\text { steted }\end{array}$ & 4 & 4 & 4 \\
\hline & Comp. & $A b ; 1$. & Abil. & Abil. & Comp. & Comp. \\
\hline
\end{tabular}


TABLE II (Continued)

\begin{tabular}{|c|c|c|c|c|c|}
\hline Folded Card & 1. Size when folded & $|6-7 n|$ & $6^{\prime \prime}-7 "$ & & $3 \frac{32^{\prime \prime}}{-1} 6^{\prime \prime}$ \\
\hline & 2. Number of pages & 4 & 4 & & 4 \\
\hline Booklet & 1. Size & & 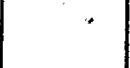 & & \\
\hline & 2. Number of paces & & & & \\
\hline Letter Faper & 1. Size & & & $8 \frac{1}{2}-\left.11\right|^{\prime \prime}$ & \\
\hline Unfolded Card & 1. Size & & & & \\
\hline $\begin{array}{l}\text { Size of Printing } \\
\mathrm{S}-\mathrm{Smal1} M-1\end{array}$ & Medium L L Large & $s$ & s & $s$ & M \\
\hline Color of Report & Card & White & $\begin{array}{l}\text { White } \\
\text { Yellow } \\
\text { Green }\end{array}$ & White & White \\
\hline
\end{tabular}

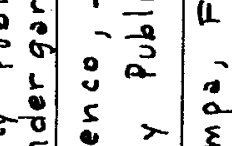

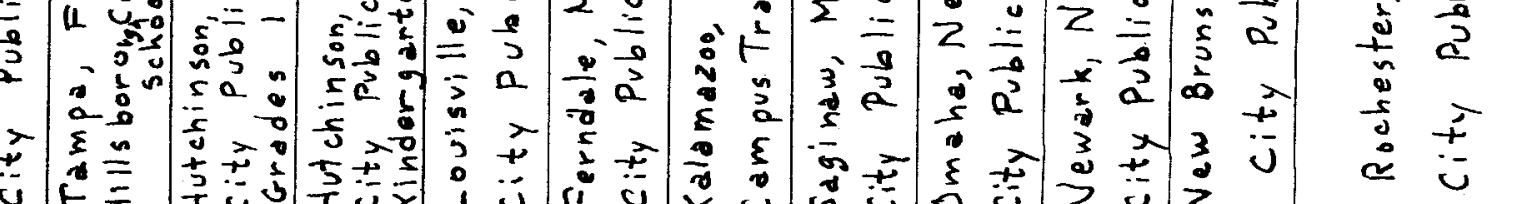

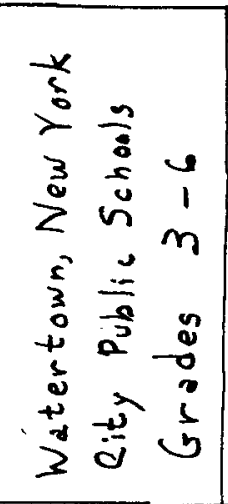

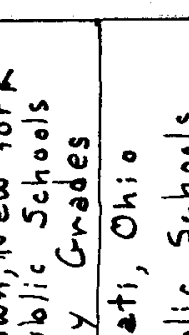

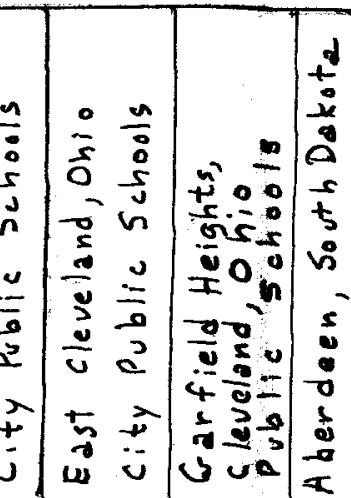

\begin{tabular}{|c|c|c|c|c|c|c|c|c|c|c|c|c|c|c|c|c|c|c|}
\hline & & $5 \frac{1}{2}-88_{2}^{\prime \prime}$ & $5^{\prime \prime}-8^{\prime \prime}$ & & $4^{\prime \prime}-6^{\prime \prime}$ & $5^{\prime \prime}-7^{\prime \prime}$ & & $4 \frac{1}{2}-8^{\prime \prime}$ & $5 \frac{1}{2}=-88_{2}^{\prime \prime}$ & $4^{\prime \prime}-6 "$ & & $5^{\prime \prime}-8^{\prime \prime}$ & $5 \frac{1}{2}-8 \frac{11}{2}$ & $5 \frac{1}{2}-8 \frac{10}{2}$ & $4 \frac{4}{2}-6 \frac{11}{2}$ & $6-82^{\prime \prime}$ & $4 \frac{11}{2}-8 \frac{11}{2}$ & \\
\hline & & 4 & 4 & & 4 & 4 & & 4 & 4 & 4 & & 4 & 4 & 4 & 4 & 4 & 6 & \\
\hline $44^{\prime \prime}-5 z^{\prime \prime}$ & & & & & & & $6=8 \frac{3}{4}$ & & & & $5 \frac{1}{2}-8 \frac{11}{2}$ & & & & & & & \\
\hline 8 & & & & & & & 12 & & & & 12 & & & & & & & \\
\hline & $8 \frac{\prime^{\prime \prime}}{2}-11 "$ & & & $5^{\prime \prime}-8^{\prime \prime}$ & & & & & & & & & & & & & & \\
\hline & & & & & & & & & & & & & & & & & & $8^{\prime \prime}-11$ \\
\hline$M$ & - & $L$ & $S$ & - & $S$ & 5 & $s$ & $s$ & $L$ & L & M & M & $M$ & M & M & $L$ & $L$ & M \\
\hline White & White & white & $\begin{array}{l}\text { Yellow } \\
\text { Blue }\end{array}$ & white & Yellow & $\begin{array}{l}\text { Pink } \\
\text { Green }\end{array}$ & white & Buff & White & Blue & White & White & $\begin{array}{l}\text { Orange } \\
\text { Blue }\end{array}$ & B/ve & Buff & white & White & Buft \\
\hline
\end{tabular}




\begin{tabular}{|c|c|c|c|c|c|c|}
\hline 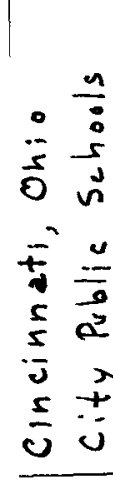 & 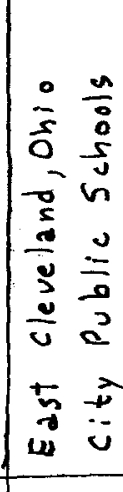 & 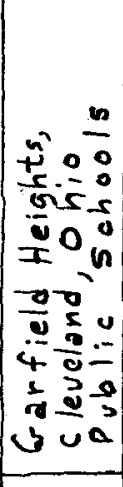 & 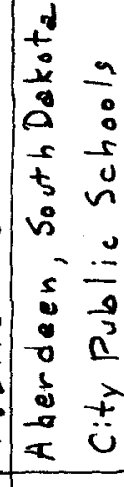 & 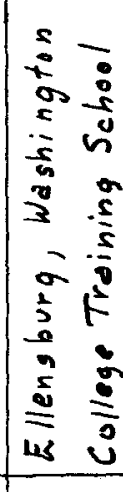 & 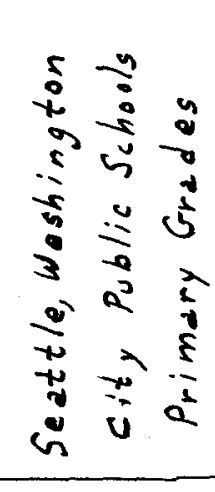 & 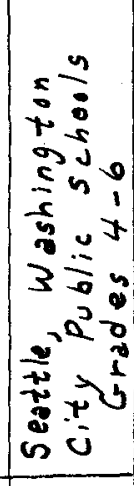 \\
\hline $4_{2}^{4}=6 \frac{1}{2}=$ & $66^{\prime \prime}-8 \frac{1}{2}$ & $4 \frac{1}{2}-8 \frac{11}{2}$ & & & $5^{\prime \prime}-8^{\prime \prime}$ & $5^{\prime \prime}-8^{\prime \prime}$ \\
\hline \multirow[t]{4}{*}{4} & 4 & 6 & & & 4 & 4 \\
\hline & & & & $5 \frac{1}{2}-8 \frac{11}{2}$ & & \\
\hline & & & & 16 & & \\
\hline & & & $18^{\prime \prime}-11 "$ & & & \\
\hline$M$ & $L$ & $L$ & $M$ & $\angle+S$ & $S$ & 5 \\
\hline off & white & White & Buff & $\begin{array}{l}\text { Blue } \\
\text { Green }\end{array}$ & white & White \\
\hline
\end{tabular}


Number of report cards used:

Elomentary public school home report cards from twentytwo roprosentatire school systems of tho Unitod states wore examined. Forty-four roport cards were oxamined in all. This is accounted for by the fact that many oities use different olementary roport card forms for difforent elomentary school grades. The distribution is as follows:

2 - lomontary school systems use 4 report forms 5 - lementary school systems use 3 report forms 6 elomontary school systoms use 2 roport forms 9 elemontary school systems use 1 roport form

The trend shows that a majority of 13 to 9 elementary school systoms use more than one form of roport card. In all but four of the elementary school systems whose report cards are included in this study, the different report cards used were found to bo similar to oach other in form that it was not folt nocessary to use separate columns to analyse them.

The following elementery school systoms were found to use suoh differing types of report cards for the primary and the Intormodiate grades that it was felt nocessary to report on thom separatoly:

Pasadena, California

Southingt on, Connecticut

Hutchins on, Kansas

Watert own, Now York

Seatt lo, Washington

Types of cards:

The report cards examined were roughly grouped into two types, tho formal type, by which is moant that there are little squares to be marked on one way or another, and the in- 
formal type, by which is meant that there are large spaces for comments by teachors, rather than littlo squares for chocking.

Number of cities using formal roport cards inolusirely in the elomontary sohools $\ldots \ldots \ldots \ldots \ldots \ldots$

Number of oities using informal report cards inclusively in the lementary schools $\ldots \ldots$

Number of schools using formal roport cards in

intormodiate grados and informal roport oards in

kindorgarten and/or primary grades

Number of schools us ing a combination of both

types of report on one card $\ldots$

Subjoct Mattor:

There is great variation in the mothods used for indicating mark in subject matter:

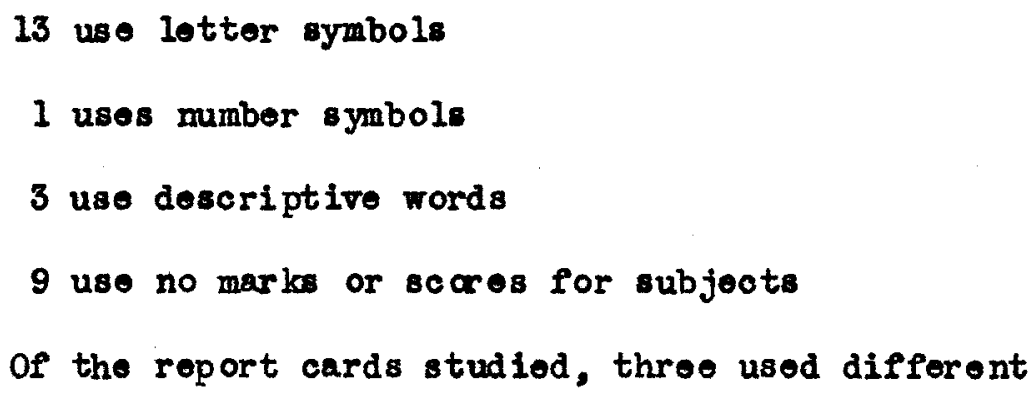

symbols for marking citizonship and social behavior from those used for marks in subject mattor.

There is also great variation in the number of steps or the grading scales. These vary from none on the informal letter reports up to five,as follows:

Table III

NUMBER OF STEPS ON GRADIMG SCALES USED ON SOME ELEMENTARY GRADE HOME REPORT CARDS:

\begin{tabular}{|c|c|}
\hline $\begin{array}{c}\text { Number of Elomentary } \\
\text { Sohool Systoms }\end{array}$ & $\begin{array}{c}\text { Number of Stops on the } \\
\text { Grading Sca lo Used }\end{array}$ \\
\hline 5 & 5 steps \\
2 & 4 stops \\
10 & 3 steps \\
2 & 2 steps \\
9 & No formal grading scale used \\
\hline
\end{tabular}


The trend soems ther of ore to be to use throe steps, on the formal cards, or else to use no steps, on informal reports.

Three lines on the chart are devoted to determining current trends in the mothods of reporting progress in silils and know lodges :

Table IV

WAYS IN WHICH SKILIS AND KNOWLEDGES ARE LISTED ON SOME ELEMENTARY GRADE REPORT

CARDS

\begin{tabular}{|c|c|c|c|}
\hline & Yos & & $\begin{array}{l}\text { Not Iisted } \\
\text { (Informal Reports) }\end{array}$ \\
\hline Subjocts are listed by one word only & 9 & $10 *$ & 8 \\
\hline Subjects are grouped into large area & 9 & $13 * *$ & 5 \\
\hline $\begin{array}{l}\text { Subjects are subdivided or analyzed } \\
\text { into specific characteristics, } \\
\text { objoctives or habits }\end{array}$ & 11 & 10 & 6 \\
\hline
\end{tabular}

* The ten report cards chooked "no" are those which list oach subject by a descriptive phrase rather than by merely one word.

** Four of these thirtoen report cards list "Social Studios" as one large area, but all other knowledges are separate subjects.

Acoording to the analysis of this small group of report cards, there is no trend or agreement on elementary report cards as to whether there should be aingle mark for oach "subjoct", as to whether oach subject should be described by a number of spocific skills or knorledges to be gained in that subject, or as to whother subject watter should be grouped into large areas, (as for oxample, history, goography and civics have been combined into the wider area, "social studies", on some of the - lementary roport cards examinod). 
Citizenship:

No elemontary report card examined stated marks in subject mattor only. All contained some type of report on citizenship.

Fourteon of the formal report cards contain oxtensive lists of traits in citizenship for checking; four have citizenship expressod in only two or throe itoms for checking.

A majarity of the elementary report cards examined mo an effort to describe citizenship in a positive way, or at loast in a noutral way, chocking somo traits satisfactory and others uhsatisfactory. The outstanding exceptions to this trend are the mothods of chocking citizenship used by the elementary schools of Louisville, Kentucky, and of Bakersfield, California. On these two report cards, only the unsatisfactory habits are chocked.

Health:

Health habits are mentioned on a majority of all the olementary school repat cards examined. Health seoms to be the topic, however, which is most neglocted. Niany of the report cards derote only one or two items to it.

The report card used in the primary grades of the Colloge Elementary School in Ellensburg, Washington, stresses hoalth habits in a comendable way. The health habits below aro: checked by the child, as part of his share in preparing his howe report: 
1. I try to koop myself neat and clean.

2. I koep hy hands and matorials away from my face.

3. I use handkorchief whon I noed it.

4. I woar my wraps when I noed thom.

5. I try to sit and stand correctly.

6. I try to relex whon resting.1

Self-ovaluation:

Although many oducators maintain that the child should have an opportunity to share in the making of his roport card, only one instance was found in which this is the case. Both of the report cards used in the College Elomentary School at Ellensburg, Washington, have spaces for the child to ovaluate himself. Statoment of philosophy and aims:

One of the criteria set up for a satisfactory report card is that it should contain a statement of the philosophy and ims of the school system. Report cards from the twenty-two - lementary school systems were checked on this point. Eleven fulfilled this requiroment; oloven did not. Home - School Cooperation:

Another criterion for a good report card is that the card should express the necessity for cooperation botween the home and the school. Four items on TABLE II deal with this subject. The following table summarizes these four items:

T.Roport to Paronts, Primary Grades. College Elementary School, El Ionsburg, Tashington, p. 3 . 
Table V

HOW HOME - SCHOOL COOPERATION IS EXPRESSED

ON SOME ELEMENTARY GRADE REPORT CARDS :

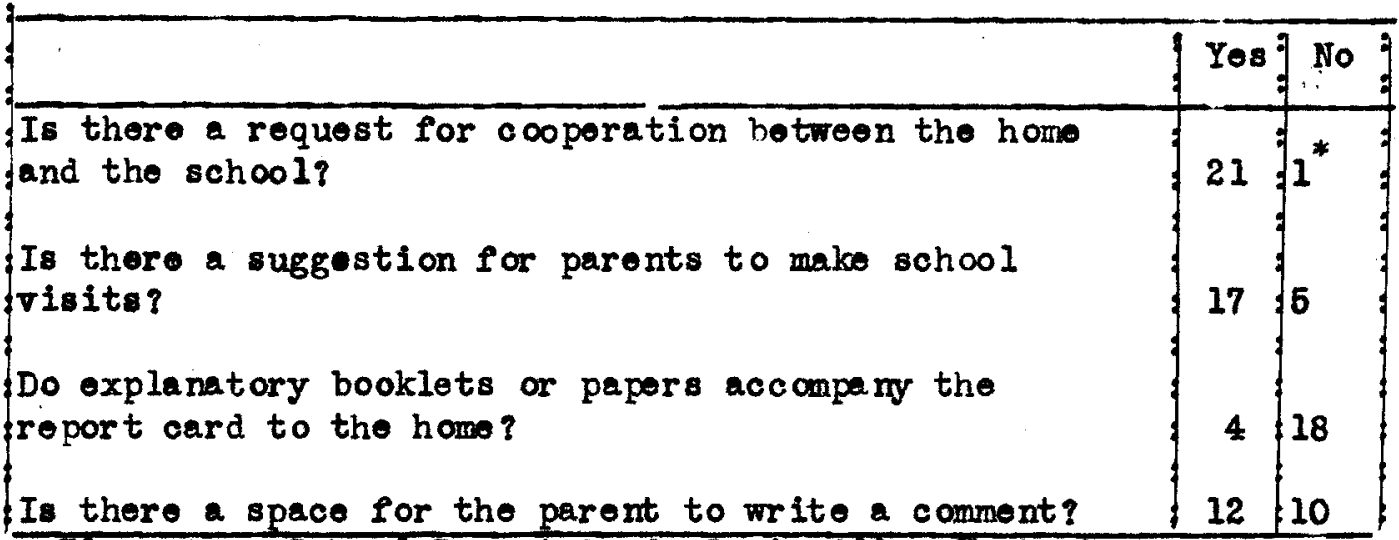

* Elementary School Report Card, Louisvillo, Kontucky.

It is ovident from this table that elementary report cards do stress cooperation botwoen home and school.

Cripe reports that less than ten minutes time is spent by parents in exemining and talking orer the roport cards now used. Indoubtedly, a contributing faotor to the ovidently insignifioant attention parents give ropart cards is that the cards aro not well understood. The same author mentioned above found in his study that parents profer a simple, understamdable roport card to one that is long, complicated, and highly technical in vocabulary. Explanatory booklots or printed sheets, at present used by only four of the twonty-two school systoms in this study, might woll. be more widely adopted, so that the parent may understand botter the ignificance of his child's roport card.

An interesting device for gaining home-school cooperation is roported from Bridgewater Township, Now Jersey, as follows:

1. Cripo, H.E. "Parents Assist in Making a Report Card." National Elenentary Principa 1, 21: 182-6, Apr 11, 1942 . 
With the quarterly report of student progress goes a letter to the parents from the hoad of the schools. This letter is usually an explanation of a school policy or an appor 1 to the parents to help oxecuto a policy. Whereas many parents disregard a form lotter sent thom $v$ ia their children, they do road a lotter which is onclosed with the roport cards. At times this letter is in the form of a questionnaire. Besides obtaining information which the schools aro anxious to gather, this reply gives thom an indication of how many parents actually road the lotters.

The informal report card is not always the most simple to understand. Not all teachors aro adequately trained in child psychology, in lotter writing or in diagnosing to be ablo to write simply and understandably about a child's progress and noeds. One public elementary school system, that of Tampa, Florida, provides a twenty-five page mimeographed hulletin consisting of lists of phrases and sentences to be used on the informal report cards. The need for such a bulletin implies that the teachers found difficult the task of interpreting the school to the home. Special Talents:

Anothor criterion for the good olementary report card is that it should contain provision for reporting to the parent concorning his child's spocial talents, skills, interests, or unusual services to his group. Only two of the formal report cards examined fulfil this requirement. It is to be assumed that the informal report cards might fulfil this requirement, dopending upon the reporting job done by the individual teacher.

1. Saunders, Carleton M. "The School and the Community Work Togethor." New Jersey Elomentary Principals. 17: No. 4, May, 1944, p. 5,6 
Froquency of reports:

It is of interest to determine how often the report cards are issued. The traditional report card was issued monthly. The trend at the present time seems to be to issue report cards loss frequently. Four of the report cards examined do not state how often they are to be issued. These four are all of the informal type. It is to be assumed that they aro is sued at irregular intervals, with the teacher writing perhaps three or four each week during the school year. Three of the elomentary public school systems have their kindergarten report issued twice a yoar and thoir othor elementary grade cards issued four timos a year. Nine of the school systoms issue all their olementary repart cards four times a year. One elementary school system issues all olementary report cards five times a yoar. Four elemontary school systeme issue all roport cards six times yoar. The trend seems to be to is sue elementary report cards four timos a year. Marking systems:

It has beon shown above that most oducators and mental hyglonists agree that competitive marking systems are dotrimental to a child's montal health. The elomentary school report cards oxamined show that twelve use competitive marking syatems while fifteon now have abandonod the competitive system of marking in favor of moasuring the child's progross against his ability to progress.

Physical charactoristics:

The physical make-up of the elementary school report card is another, though a minor, problem. The concensus of 
opinion in articles read on the subject seems to be that the home report should be of a ploasing color, perhaps have an interesting picture on the cover, and otherwise be made attractive to the child. Many are of the opinion that report cards should bo of a size that will fit into a standard size envelope for mailing. The following is a sumary of the physical characteristics of the olementary school report cards examined.

Ninetoen are folded cards. Eighteon of these have only ono fold, making four pages to the repat. One has two folds, making six pages to the report. The folded cards vary from $3 \frac{7}{2}$ " by 6 " to $6^{\text {"I }}$ by $8 \frac{1}{2}$ " in size.

Four of the report cards are booklets containing fran oight to sixtoen pages. The booklets vary in size from $4 \frac{i_{4}^{n}}{4}$ by $5_{4}^{3 n}$ to $6^{\prime \prime}$ by $8 \frac{3 n}{4}$.

Two reparts are ordinary letter size $8 \frac{7 n}{2}$ by $11^{\prime \prime}$. One is noto paper $5^{\prime \prime}$ by $8^{n}$.

Nine of the report cards are in small print, seven are in medium size print, and only five use print large enough to compare favorably with the size print in textbooks used by childron in the grades for which the reports are intended.

Fifteon of the elementary schol systems use plain white or buff cards, while seren use cards colored yollow, blue, groen, pink or orange.

One elementary school system uses cards with an interosting pieture on the cover; another uses a booklet with an islustration on the second page. 
IV. An Elomentary Report Card Suggested for Discussion and Irial in a Second Grade of a Louisville Public School

The Works Survey contains the following comment concerning home roparts in Louisvillo, Kontucky:

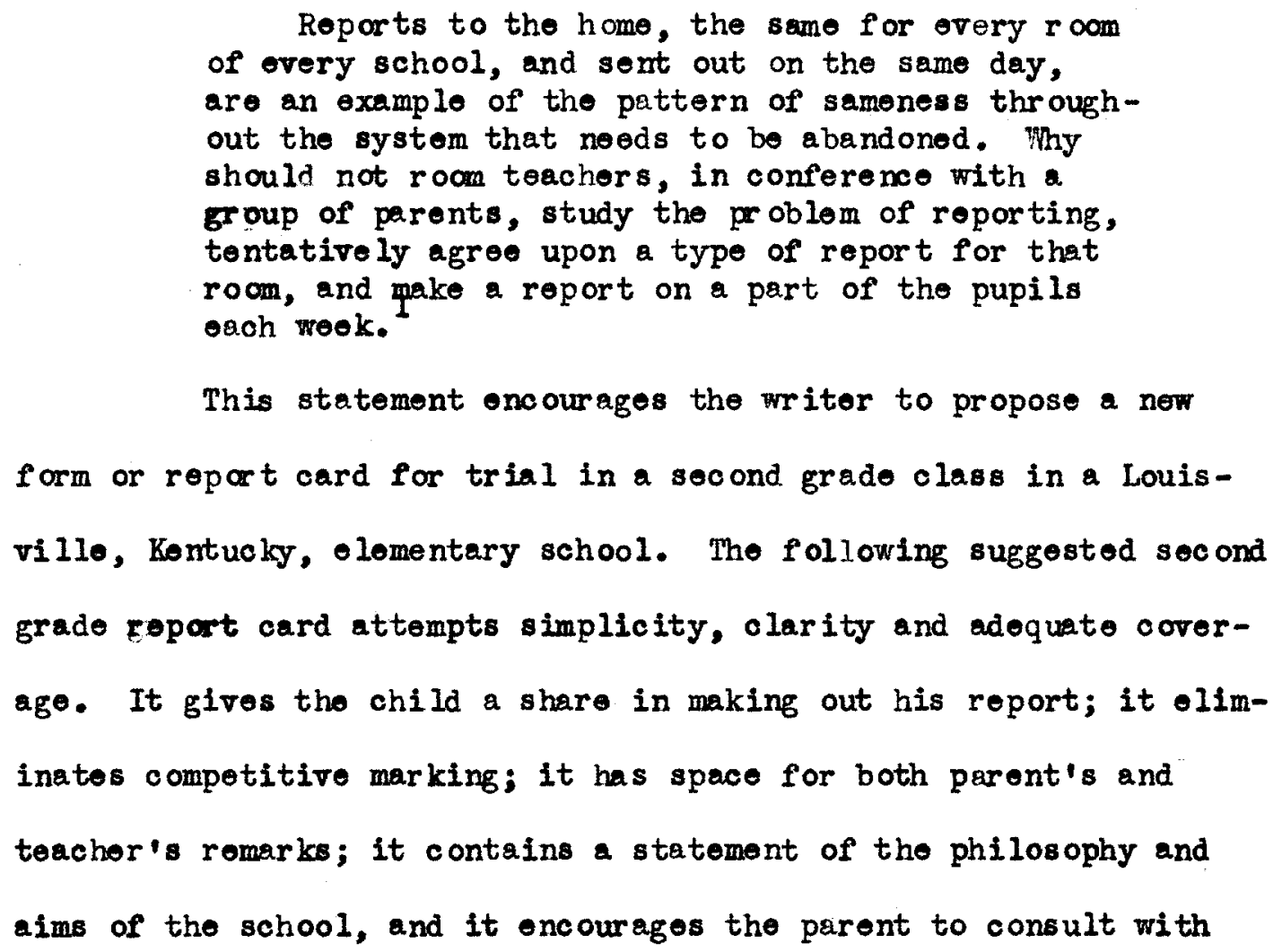

This repart contains ten pages. However, the teacher's actual work takos up moroly throe and a fraction pages. As matter of fact, thero is very littlo more work than is entailed in the regularly adopted Louisville Public School Elementary Report card, since the number of pages is partly due to the large size printing purposely employed.

Four pages of tho ropart card aro designated "Pupil's

1. Vorke, Georgo A. Survey Report of the Louisville Public Schools. Printed by the City of Louisvilie, Kentucky, 1943, p. 256-257. 
Report." This part of the card is mant to be cheoked by oach child during a classroom supervised study lesson. After the first time ot two that the report card is used, the children should bo able to chock thoir cards with littlo help. The child's part of the report card should be propared before the teacher adds her romarks and grades. The child's part of the ropat card, consisting of citizenship and hoalth traits, omploys a different systom of scoring than the teachor's part, for the sake of oasier scoring. The spaces are checked ungr the appropriate phrases. The teacher's part of the report, consisting of growth in subjoct matter, omploys the three step scoring shown to be preforred on most of the elomentary roport cards examined. The lotters U (Unsatisfactory), $S$ (Satisfactory) and I (Improving) aro used to rate the child in consideration with his own ability. The lotter "I" cannot be used except to follow "V". Therefore the first repat card will show grades of oither "S" or "U".

This report card is designed to be issued only four times a yoar, rathor than the six times indicated on the prosently employed roport card. This is in accordance with the trond discoored through examining many report cards, and incidentally makes up for the slight amount of extra work involved in this suggested new form. 


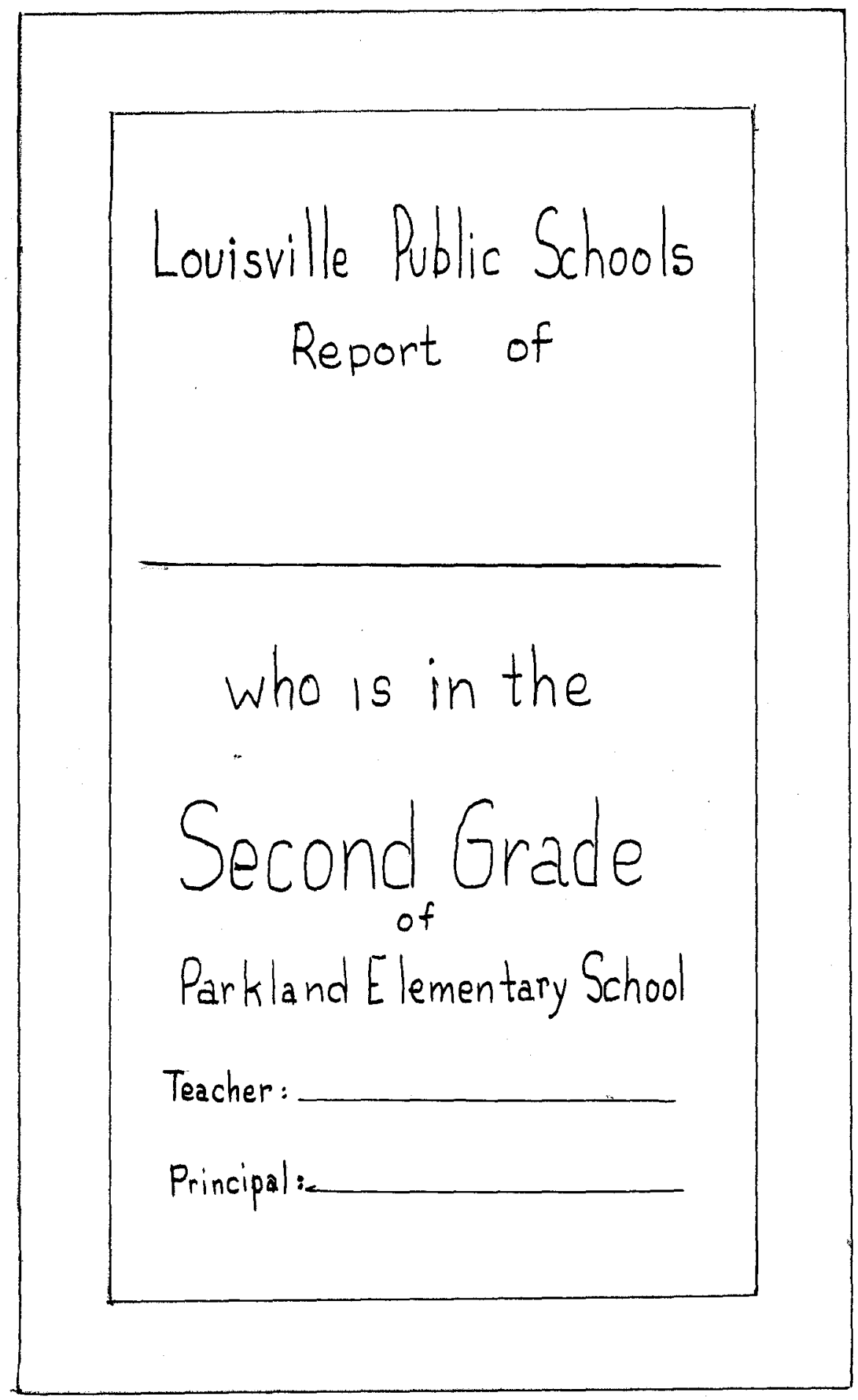

SAIMPE IV. FRONT COVWR OF PKOPOSED REPORT CARD 


\section{MESSAGE TO PARENTS}

Schools are to build woll-rounded individuals, who are deroloped not only mentally, but physically, socially and motional ly as woll.

This is a report concerning your child. It has boen designed to call your attention to important phases of his $\alpha$ her dovelopment. All childron do not progress at an equal rate. Therofore, this roport card does not compare your child's work with that of any other child. Instead, his achievoment is compared with his own past record and ability.

It is our belief that the school and the home must cooperate to seoure the child's best monta 1, physical, social and emotional growth. Your child has aidod in proparing this report. You are askod to examine this report oarefully and discuss such parts of it with the child as will bo of adrantage to him.

A space has been reserved at the ond of this report for you to ke your suggestions and comments.

You are urged to visit the school and confer with the teachor.

It is advisable that appointmonts with tho teacher be made in advance. Please phone the office of the school for appointments. 


\begin{tabular}{l} 
CHILD'S REPORT \\
\hline LIVING TOGETHER \\
\hline 1. I help my group to make plans. \\
\hline 2. I help to carry out the plans. \\
\hline 3. I work carefully. \\
\hline 4. I am an independent worker. \\
\hline 5. I try to finish my work. \\
\hline 6. I find worthwhile things to do by myself. \\
\hline 7. I try to use a pleasant voice. \\
\hline 8. I do not interrupt when others are talking. \\
\hline 9. I am courteous and considerate of others. \\
\hline 10. I am dependable. \\
\hline 11. I help make our school a happy place. \\
\hline
\end{tabular}




\begin{tabular}{l} 
CHILD'S REPORT \\
\hline KEEPING WELL AND STRONG \\
\hline 1. I keep myself neat and clean. \\
2. I keep things out of my mouth. \\
\hline 3. I use a hand kerchief when I need it. \\
\hline 4. I wear my wraps when I need them. \\
\hline 5. I try to sit and stand correctly. \\
\hline 6. I choose a good lunch. \\
\hline 7. I get 10 hours sleep at night. \\
\hline 8. I brush my teeth morning and night. \\
\hline Teacher's comments on" Living Together and" Health" if necessary. \\
\hline \\
\hline \\
\hline
\end{tabular}


$-42-$

\begin{tabular}{l} 
6. TEACHER'S REPORT \\
Meaning of symbols: \\
S-Satisfactory U -Unsatisfactory I-Improving \\
\hline \multicolumn{3}{|l|}{} \\
\hline
\end{tabular}

SAMPLE IV. PAGE SIX OF PROPOSED REPORT CARD 


\begin{tabular}{|c|c|c|c|c|}
\hline & \multicolumn{4}{|c|}{ PERIODS: 7} \\
\hline & 1. & 2 & 3 & 4 \\
\hline $\begin{array}{l}\text { ARITHMETIC: } \\
\text { 1. Knows the number facts. }\end{array}$ & & & & \\
\hline 2. Solves problems. & & & & \\
\hline $\begin{array}{l}\text { SOCIAL S TUDIES: } \\
\text { 1. Takes part in discussions. }\end{array}$ & & & & \\
\hline 2. Reads informational books. & & & & \\
\hline 3. Brings in materials for study. & & & & \\
\hline $\begin{array}{l}\text { SCIENCE: } \\
\text { 1. Takes part in experiments. }\end{array}$ & & & & \\
\hline 2. Brings in materials for experiments. & & & & \\
\hline $\begin{array}{l}\text { ART: } \\
\text { 1. Expresses ideas through art materials. }\end{array}$ & & & & \\
\hline 2. Uses materials skillfully. & & & & \\
\hline $\begin{array}{l}\text { Muslc: } \\
\text { l. Listens to good music. }\end{array}$ & & & & \\
\hline 2. Takes part in music activities. & & & & \\
\hline 3. Sings correctly with the group. & & & & \\
\hline 4. Sings correctly alone & & & & \\
\hline $\begin{array}{l}\text { SUPERVISED PLAY: } \\
\text { 1. Takes part in games readily. }\end{array}$ & & & & \\
\hline
\end{tabular}

SAMPLE IV. PAGE SEVEN OF PROPOSED FEPORT CARD 


\begin{tabular}{|l|l|l|l|l|}
\hline 8 & \multicolumn{3}{|c|}{ PE RODS } \\
\hline & 1 & 2 & 3 & 4 \\
\hline Height (inches) & & & & \\
\hline Weight & & & & \\
\hline Days present & & & & \\
\hline Days absent & & & & \\
\hline Times tardy & & & & \\
\hline Teacher's remarks, including special \\
talents, skills and contributions to the group: \\
Period I:
\end{tabular}

SAMPLE IV. PAGE EIGHT OF PROPOSED REPORT CARD 


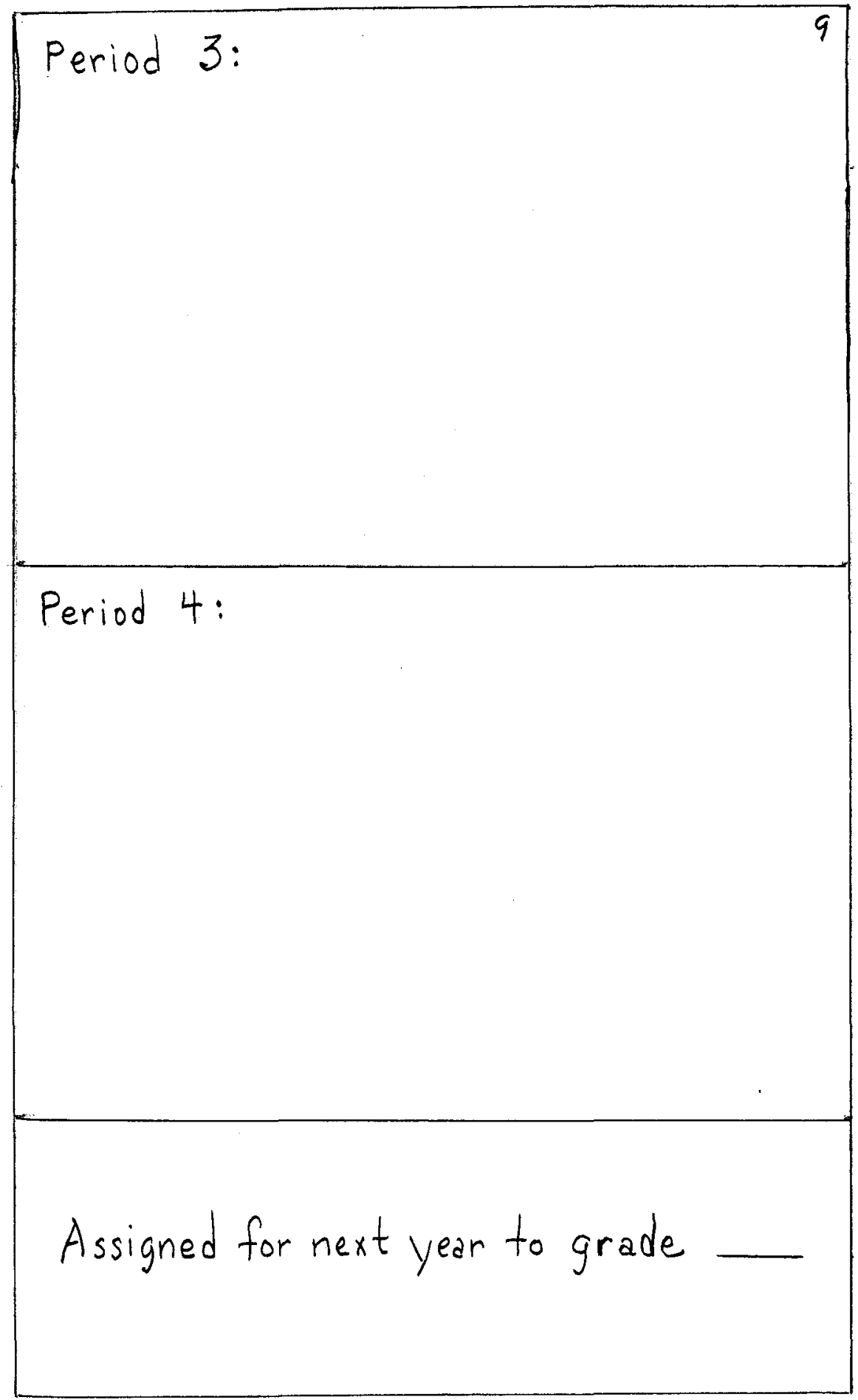

SAMPLE IV. PAGE NINE OF PROPOSED REPORT CARD 


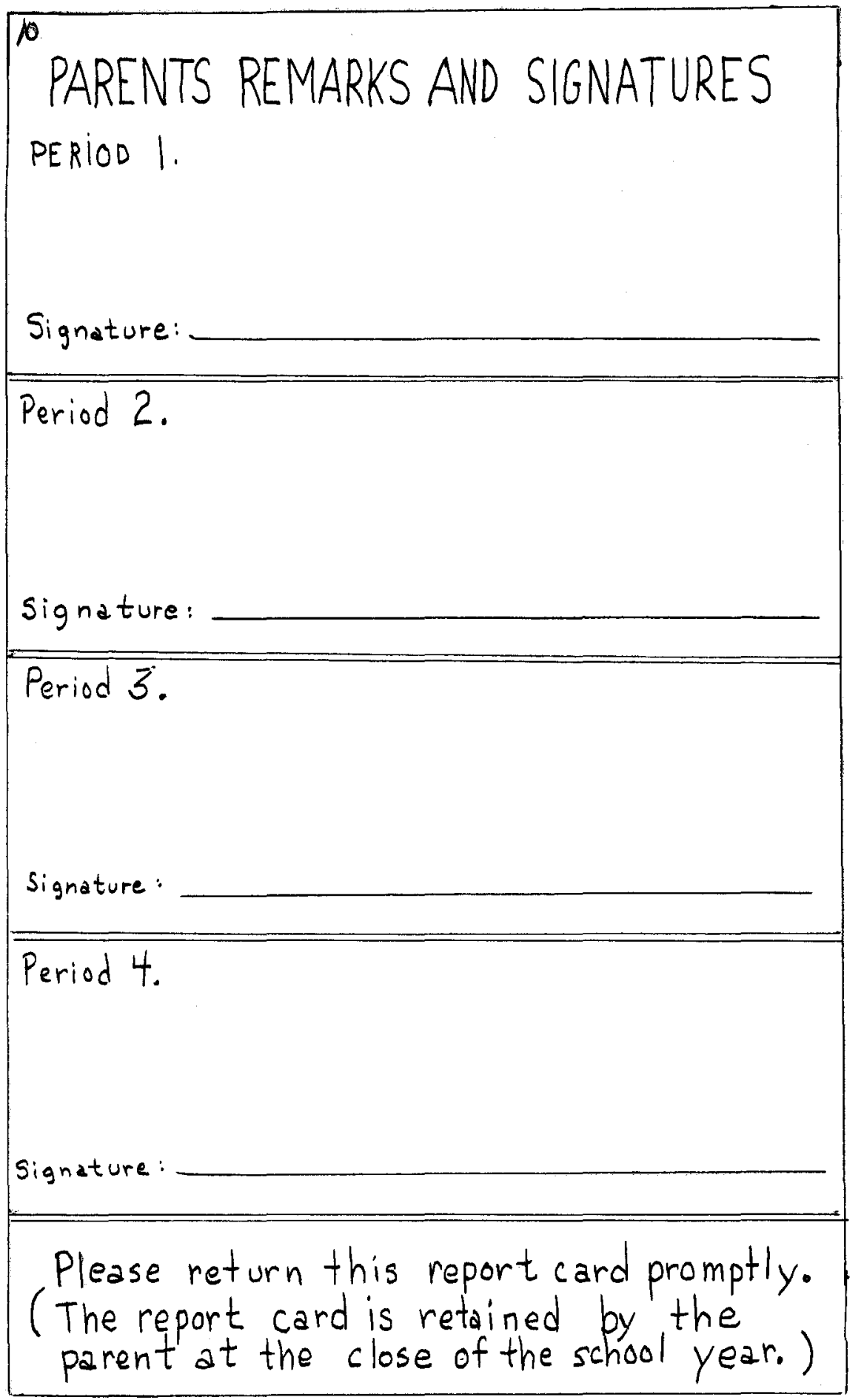

SAMPLE IV. PAGE TEN OF PROPOSED REPORT CARD 
V. Conclusion

Critoria have boen sot up for reporting to the hom on the progress of elementary school children. Same of the psychologioal implications of home reporting on the mental hoalth of childron hare boen mentioned. A group of representative elomontary grade report cards has boon oxamined and comparod. Upon the knowledges gained through tho se activities, a tentative form of report card for a second grade class has been designed. Its value cannot be ascortainod until it has been thor oughly disoussed by paronts and teachers, and tosted through actual uso. 


\section{Bibllography}

1. "Appraising Now Report Fores." Educational Loadership, 2: 295-300, April, 1945.

2. Association for Childhood Eduoation. Rocords and Roports. Washington, D.C.: The Association, 1942. 32p.

3. Baker, H.V. "Reporting Pupl l Progress to Parents." National Elementary Principal, 23: 32-34, Juno, 1944.

4. Berman, Semue 1. "Revising the Junior High School Report Card." National 1880 iation of Socondary School Principals Bullotin, 27: No. 115, 12y, 1943.

5. Bristor, Norma S. "Variety in Reporting to Parents." School Executire, 62: 28-30, June, 1943.

6. Burton, William H. "War king and Reporting Progres8." The Guidance of Loarning Activities, p. 479-513. Now Yar: D. Apploton-Contury compan, 1944 .

7. Carradine, Jane C. "On Sooring Pupils for Thoir Roport Cerds." National Elementary Princ 1pa 1, 25: 35-38, October, 1945.

8. Cripe, H.F. "Other Side of the Report Card." Hyge1e, 19: 860862, Dotober, 1941.

9. Cripe, H.E. "Parents Assist in laking a Report Card." National Elementary Principal, 21: 182-186, April, 1942.

10. Cumings, R.L. "Now Roport Cards." Grade Toacher, 64: 94, September, 1946.

11.Davis, Mary D. Roport Card Book No, 10. Washington, D.C.: United States Offlco of Education, 1945.

12. Goldstein, Henry M. "Pup1l Rating and Report Cards." Journal of Educational Mothod, 7: 128-133, December, 1927.

13. Hamalainon, Arthur E. "Evaluating Growth of Individual Childron." Elementary School Journal, 41: 359-367, December, 1940.

14. Hamalainon, Arthur E. "Bxisting Practices in the Evaluation Pupil Growth in the Elomentary School." Elonontary School Journa 1, 42: 175-182, November, 1941. 
15. Hansen, Roma. Report Cards for Kindergarten and Elementary Grades. United States Office of Education Leaflot No. 41.

16. Hook, Arch 0. "Repart Cards." Encyclopedia of Mod or n Education, p. 667-668. How York: Philosophioal Library of Now YorkC1ty, 1943.

17. Heck, Arch 0. "Reporting to Parents." Administration of Pixpil Porsonnol, p. 275-297. Boston: Gim and Company, 1929.

18. Houle, C.0. "School Reports." Elementary School Journal, 47: 428, April, 1947.

19. Eufstedler, Virginia. "Paronts and Teachers Talk It Over." Educational Leadorship, 4: 429-432, April, 1947.

20. Huggett, Albert J. and Mllard, Cecil V. "Reporting to Parents." Growth and Loarning in the Elementary School, p. 346-401. Boston: D.C. Hoath and Compary, 1946.

21. Irish, Botty. "What is a "Good' Report Card." Educational Loadership, 4: 433-434, April, 1947.

22. Kirkenda 11, Lester A. "Problems of an Evaluation Program." Eduoational Administration and Supervision, 29: 377-382, Septomber, 1943 .

23. Indel, Albert L. and Mohr, Allene. "Now Report Card." National Elomontary Principa 1, 25: 39-41, Detober, 1945.

24. Nottear, W.M. "How California Elementary Schools Report to Parents." California Journal of Elementary Education, 10: 135 - 161, Fobruary, 1942.

25. National Education Association. Department of Classrocm Teachers and Research Division. School Yarks and Promotions. Discussion Pamphlet No. 9. Washington, D.C.: The Dopartment, 1946. 23 p.

26. No111, A.S. The Problom Toacher. Now York: International University Pro88, 1944. $161 \mathrm{p}$.

27. Ojemam, R.H. and YoCandless, R.A. "Suggestions for a Fundamontal Rovision of Roport Cards." Educational Administration and Supervision, 32: 110-116, Fobruary, 1946.

28. Otto, Homy J. "Roporting Pupil Progross." Elomentary School Organization and Administration (Socond Edition.), p. 243247. Now York: D. Apploton-Century Company, 1944. 
29. Foters, F.B. "Eliminating Failure in the Primary Grades by Fitting the School to the Child." Educational Administration and Supervision, $28: 20-30$, January, 1942.

30. "Parents and Teachers Revise the Report Card." National Association of Socondary School Principals BuljeEIn, 30: 50-56, October, 1946 .

31. Preston, George H. The Substance of Hental Health. Now York: Rinohart and Company Inc., 1943. $147 \mathrm{p}$.

32. Rayne, E.W. "And Now to Hake Out Grades." Educational Mothod, 21: 387-390, May, 1942.

33. Rioe, Jean C. "Moaningful Reports." Instructor, 54: 28, June, 1946.

34. Roos, C.A. "Roport Card Designed to Enlist the Parents" Cooporation in Rating and Guiding the Child." Amorican School Board Journal, 107: 28, August, 1943.

35. Rossman, Mablo. "An Experiment in Reparting Pupil Progross to Parents." Personality Adjustment of the Elementary School Child. National Education Association. National Elomontary Principal. Fifteonth Yoarbook, p. 364-367. Washington, D.C.: The Department, 1936.

36. Saunders, Carleton M. "Tho School and the Community Work Together." New Jersey Elementary Principals, 17: 5-6, May, 1944.

37. Sheppard, Mildred. "Johnny Looks at Himself." Educational Leadorship, 3: 76-80, November, 1945.

38. Shulkoy, Bruce C. " Evaluation of Pupil Growth in the Elemontary School." National Elementary Principal, 23:31, Juno, 1944.

39. Teagarden, Florence M. Child Psychology for Professional Wor kors, p. 437-438. Now York: Prontice Fall Inc., 1946.

40. Van Loan, W.L. and Williams, M. "Reporting Pupil Progress to Parents." Elementary School Journa 1, 44: 215-222, Decomber, 1943.

41. Wills, Olin J. "Now Roports for Old." Educational Loadership, 4: 435-438, April, 1947.

42. Works, George A. Survey Report of the Louisville Public Schoole, p. 256-257. Louisvillo: Printed by City of Louisvillo, Kontucky, 1943. 